\title{
Salacia pallescens Oliv. (Celastraceae) Scavenges Free Radicals and Inhibits Pro-inflammatory Mediators in Lipopolysaccharide-activated RAW Cells 264.7 Macrophages
}

\author{
Lipopolisakkarit ile Aktive Olan RAW Hücreleri 264.7 Makrofajlarda \\ Salacia pallescens Oliv. (Celastraceae) Serbest Radikalleri Uzaklaştırması ve \\ Pro-inflamatuvar Mediatörlerini İnhibe Etmesi
}

\author{
(D) Oyindamola Olajumoke ABIODUN ${ }^{1,2 *}$, (D) Tolulope Aderinola OKE ${ }^{2}$, (D) Faridah Oyinkansola ADEYEMI ${ }^{1}$, (D) Adedunke Omobolanle OSHINLOYE 3 , \\ (D) Adesewa Omolola AKANDE1
}

1Department of Pharmacology and Therapeutics, College of Medicine, University of Ibadan, Ibadan, Nigeria

2Department of Pharmacology and Toxicology, Faculty of Pharmacy, University of Ibadan, Ibadan, Nigeria

3Department of Pharmacology and Toxicology, Faculty of Pharmacy, Federal University Oye-Ekiti, Oye-Ekiti, Nigeria

\begin{abstract}
Objectives: Salacia pallescens has folkloric anti-inflammatory claims, with little scientific investigation. Hence, the antioxidant and anti-inflammatory effects along with phytochemical components of the plant were investigated.

Materials and Methods: The antioxidant property of S. pallescens leaf (SPL) methanol extract was evaluated using 1,1-diphenyl-2-picrylhydrazyl and nitric oxide inhibition assays. The anti-inflammatory property of SPL in lipopolysaccharide-stimulated RAW 264.7 macrophages was determined. The cytotoxicity of SPL was assessed in brine shrimp lethality assay (BSL) and against RAW 264.7 cells in a 3-(4,5-dimethylthiazol-2-yl)-2,5diphenyltetrazolium bromide based assay. Gas chromatography-mass spectrometry was employed to identify SPL phytochemical compounds.

Results: SPL significantly scavenged free radical generated in the antioxidant assays and inhibited nitrite production in stimulated RAW 264.7 cells. Similarly, there was a 9-fold reduction in interleukin-6 produced in RAW 264.7 cells when exposed to the highest concentration of SPL. In addition, $50 \%$ lethal concentration of SPL was $455.58 \pm 82.35 \mu \mathrm{g} / \mathrm{mL}$ while cyclophosphamide gave $16.3 \pm 0.15 \mu \mathrm{g} / \mathrm{mL}$ in BSL test. Moreover, cell viability was not affected by SPL. Sixteen compounds were identified from SPL where thymol (29.79\%), 3-carene (15.97\%), and p-cymene (12.19\%) are the most abundant.

Conclusion: Methanol extract of SPL showed antioxidant and anti-inflammatory activities by free radicals and cytokines inhibition. The activity observed may be related to the polyphenolic compounds in the plant.
\end{abstract}

Key words: Anti-inflammation, antioxidant, Salacia pallescens

Öz

Amaç: Salacia pallescens, çok az bilimsel araştırma ile folklorik anti-inflamatuvar iddialara sahiptir. Bu nedenle bitkinin fitokimyasal bileşenleri ile birlikte antioksidan ve anti-inflamatuvar etkileri araștırılmıştır.

Gereç ve Yöntemler: S. pallescens yaprağı (SPL) metanol ekstresinin antioksidan özelliği, 1,1-difenil-2-pikrilhidrazil ve nitrik oksit inhibisyon deneyleri kullanılarak değerlendirilmiştir. Lipopolisakkarit ile uyarılan RAW 264,7 makrofajlarda SPL'nin anti-inflamatuvar özelliği belirlenmiştir. SPL'nin sitotoksisitesi, tuzlu su karides ölümcül tahlilinde (BSL) ve 3-(4,5-dimetiltiyazol-2-il)-2,5-difeniltetrazolyum bromür bazlı bir tahlilde RAW 264,7 hücrelerine karşı değerlendirilmiştir. SPL fitokimyasal bileşiklerini tanımlamak için gaz kromatografisi-kütle spektrometrisi kullanılmıştır.

*Correspondence: oyindamolaabiodun1@gmail.com, Phone: +2347030964774, ORCID-ID: orcid.org/0000-0002-6629-3016

Received: 04.01.2021, Accepted: 09.03.2021

๑Turk J Pharm Sci, Published by Galenos Publishing House. 
Bulgular: SPL, antioksidan deneylerde üretilen serbest radikali önemli ölçüde uzaklaştırmış ve uyarılmış RAW 264,7 hücrelerinde nitrit üretimini inhibe etmiştir. Benzer şekilde, en yüksek SPL konsantrasyonuna maruz bırakıldığında RAW 264,7 hücrelerinde üretilen interlökin-6'da 9 kat

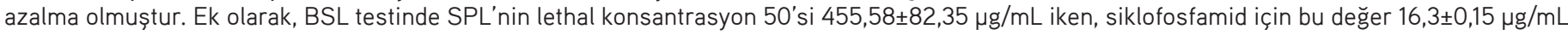
olarak belirlenmiștir. Ayrıca, hücre canlılığı SPL'den etkilenmemiștir. SPL'den on altı bileșik tanımlanırken, bunların aralarında en çok olanları timol $(\% 29,79), 3-k a r e n(\% 15,97)$ ve $p$-simenindi $(\% 12,19)$.

Sonuç: SPL'nin methanol ekstresi, serbest radikaller ve sitokinlerin inhibisyonu ile antioksidan ve anti-inflamatuvar aktiviteler göstermiştir. Gözlenen aktivite, bitkideki polifenolik bileşiklerle ilgili olabilir.

Anahtar kelimeler: Anti-inflamatuvar, antioksidan, Salacia pallescens

\section{INTRODUCTION}

Inflammation is the host defensive immune response to tissue damage or infection. Inflammation aims at localizing, eliminating, removing infecting agent, or repairing the injured tissue. In order to achieve these goals, the innate immune system tissue-resident cells discover the toxic insult and alert circulating neutrophils, which then proceed to the inflamed tissue. ${ }^{2}$ Thus, promoting inflammatory monocyte recruitment and potentiating pro-inflammatory mediators such as cytokines and chemokine to handle the situation appropriately. ${ }^{3}$ This process can cause reactive oxygen species (ROS) formation, vital signaling molecules that play a crucial part in the initiation, progression, and resolution of inflammatory response. ${ }^{4}$ An increased ROS production by polymorphonuclear neutrophils at the inflammation area leads to tissue injury and endothelial dysfunction. However, neutrophils undergo apoptosis under normal conditions after executing their roles. ${ }^{5}$ The removal of apoptotic neutrophils prompts a change from a pro- to an anti-inflammatory macrophage phenotype.,7 Nonetheless, when inflammation is unresolved, it can progress to chronic inflammation. The persistence of chronic inflammation can result in cardiovascular, neurodegenerative, and respiratory diseases, including cancer. ${ }^{8}$

Drugs for inflammation treatment are effective but have serious side effects when used for prolonged time. For this reason, it is crucial to search for new and safe anti-inflammatory agents. Medicinal plants are valuable source of novel molecules and efficient alternative strategy for newer therapeutics development. ${ }^{9}$ Many plants have been documented in traditional medicine to ameliorate various inflammatory disorders. ${ }^{10}$ Salacia pallescens is a plant commonly known as Elewekan in the Yoruba ethnomedicine. It is used in folk medicine as an ingredient for a decoction to treat children," particularly fever and pain. However, pharmacological activities of this plant are not readily available except for antioxidant activity. ${ }^{12}$ Antidiabetic, anti-inflammatory, antioxidant, anticancer, nephroprotective, or hepatoprotective activities of other species of Salacia such as S. chinensis, S. oblonga, S. reticulata, S. reticulate, Salacia parviflora, S. lehmbachii, S. senegalensis, and S. crassifolia have been reported. ${ }^{13-20}$ Therefore, this is the first report on $S$. pallescens anti-inflammatory activity and chemical composition.

\section{MATERIALS AND METHODS}

\section{Plant material}

Salacia pallescens leaf (SPL) was collected from Idi-Ayunre, Ibadan. A sample was taken for identification and authentication at the Forestry Research Institute of Nigeria (110527).

\section{Extraction of the leaf of S. pallescens}

The leaf of $S$. pallescens was air-dried and coarsely ground. Then, $206 \mathrm{~g}$ of SPL was macerated in 50\% methanol for 72 h. Subsequently, the methanol extract was concentrated at reduced temperature and pressure. The extraction process was done thrice to increase the yield. The SPL methanol extract was stored at $4^{\circ} \mathrm{C}$ for further use.

\section{Determination of total flavonoid content (TFC)}

The method previously reported was used to determine TFC. ${ }^{21}$ Briefly, $0.6 \mathrm{~mL}$ of SPL ( $1 \mathrm{mg} / \mathrm{mL}), 6.8 \mathrm{~mL}$ of $30 \%$ methanol, 0.30 $\mathrm{mL}$ of $0.5 \mathrm{M}$ sodium nitrite, and $0.30 \mathrm{~mL}$ of $0.3 \mathrm{M}$ aluminum chloride hexahydrate were mixed. Five minutes later, $2 \mathrm{~mL}$ of $1 \mathrm{M}$ sodium hydroxide was added into the mixture, and the absorbance was read at $506 \mathrm{~nm}$. TFC was reported as milligrams of rutin equivalents (RE) per gram of dried plant sample.

\section{Determination of total phenolic content (TPC)}

The TPC of SPL was estimated by a spectrometric method. ${ }^{22}$ An equal volume $(0.1 \mathrm{~mL})$ of SPL $(1 \mathrm{mg} / \mathrm{mL})$ and Folin and FolinCiocalteuphenol reagent were mixed. After 5 min incubation, 1.3 $\mathrm{mL}$ of distilled water and $1 \mathrm{~mL}$ of $7 \% \mathrm{Na}_{2} \mathrm{CO}_{3}$ were added into the mixture. Absorbance at $750 \mathrm{~nm}$ was read after $90 \mathrm{~min}$. TPC was reported as milligrams of gallic acid equivalents (GAE) per $\mathrm{g}$ of the dried sample.

\section{Antioxidant assays}

\section{1,1-diphenyl-2-picrylhydrazyl (DPPH) scavenging activity of} SPL

SPL antioxidant activity by DPPH assay was estimated using a method previously reported. ${ }^{23}$ Briefly, gradient concentrations of SPL $(6.25-400 \mu \mathrm{g} / \mathrm{mL})$ or standard ascorbic acid $(0.25-16$ $\mu \mathrm{g} / \mathrm{mL}$ ) were prepared in a 96 microtiter well plate, incubated for $30 \mathrm{~min}$ at $29^{\circ} \mathrm{C}$ in the dark after the addition of a freshly prepared solution of DPPH $(0.04 \mathrm{mg} / \mathrm{mL})$. The absorbance at $517 \mathrm{~nm}$ was read against the blank, and values obtained were expressed as the percentage of the control. 
Nitric oxide scavenging activity of SPL

Antioxidant activity of SPL by nitric oxide inhibition assay was determined following a modified method of Panda et al. ${ }^{24}$ Sodium nitroprusside solution $(40 \mathrm{mM})$ was mixed with graded concentrations $(50-800 \mu \mathrm{g} / \mathrm{mL})$ of SPL $(1: 4 \mathrm{v} / \mathrm{v})$ and incubated at $29^{\circ} \mathrm{C}$ for $2 \mathrm{~h}$ in the dark. Then, an equal volume of the incubated test solution and Griess reagent (1\% sulphanilamide and $0.1 \% \mathrm{~N}$-naphthyl-ethylenediamine dihydrochloride in $2.5 \%$ phosphoric acid) were added into a 96-well plate in duplicate and kept for an additional $15 \mathrm{~min}$ at $29^{\circ} \mathrm{C}$ in the dark. Absorbance at $550 \mathrm{~nm}$ was read. The amount of nitric oxide generated was extrapolated from the sodium nitrite curve.

\section{Cell viability testing}

RAW 264.7 cell line from the American Type Culture Collection (TIB-71; Rockville, MD, USA) maintained in cultured Dulbecco's modified eagle medium, $10 \%$ fetal bovine serum supplemented, $2 \mathrm{mM} \mathrm{L}$-glutamine, and $100 \mathrm{IU} / \mathrm{mL}$ of penicillin-100 $\mathrm{\mu g} / \mathrm{mL}$ streptomycin, at $37^{\circ} \mathrm{C}$ in $5 \%$ carbon dioxide incubator was used. SPL effect on cell viability was determined following a previously published method. ${ }^{25}$ RAW 264.7 cells $\left(5 \times 10^{5}\right.$ cells/ $\mathrm{mL}$ ) were placed in a 96 microtiter well plate for $18 \mathrm{~h}$ prior to exposure to a graded concentration of SPL for $2 \mathrm{~h}$. The cells were subsequently stimulated with $100 \mathrm{ng} / \mathrm{mL}$ liposaccharide from Escherichia coli 055: B5 for $24 \mathrm{~h}$. Thereafter, the cultured medium was substituted with $0.5 \mathrm{mg} / \mathrm{mL} 3$-(4,5-dimethylthiazol2-yl)-2,5-diphenyltetrazolium bromide (MTT) in culture medium and further incubated for $2 \mathrm{~h}$. The formazan blue formed due to the addition of MTT was dissolved with DMSO. Absorbance was read at $540 \mathrm{~nm}$.

\section{Anti-inflammatory testing}

The SPL effect on nitrite and interleukin-6 (IL-6) produced in liposacharride (LPS) stimulated RAW 264.7 cell was determined. RAW 264.7 cells were seeded at $5 \times 10^{5}$ cells per well in a 24-well plate and permitted to grow into confluence before exposure to a graded concentration of SPL $(50-400 \mu \mathrm{g} / \mathrm{mL})$ for $2 \mathrm{~h}$. The cells were subsequently stimulated with $100 \mathrm{ng} / \mathrm{mL}$ LPS, and the plate was incubated for $24 \mathrm{~h}$. The nitrite content in the supernatant was estimated using the Griess reagent. ${ }^{26}$ The IL-6 level in the supernatant was determined using mouse IL-6 ELISA MAX deluxe kit according to the manufacturer's instruction.

\section{Brine shrimp lethality assay (BSL)}

The SPL cytotoxicity was evaluated using BSL according to the method previously reported. ${ }^{27}$ Artemia salina (brine shrimp eggs) was purchased at an Aquarium shop in the UK. The nauplii (larvae) were hatched by placing the eggs of $A$. salina in a tank containing seawater at $29^{\circ} \mathrm{C}$. One part of the tank was exposed to light, and the other was covered with aluminum foil. The eggs were hatched after $48 \mathrm{~h}$ to nauplii which were attracted to light. Ten nauplii were transferred into graded concentrations of SPL extract $(1.0-1.000 \mu \mathrm{g} / \mathrm{mL})$ in plain test tubes. Cyclophosphamide drug was a positive control.

\section{Chemical composition of SPL}

The SPL phytochemical compounds were identified using an Agilent technologies 7890 gas chromatography system with a 5975 mass spectrometry (MS) following a previously described method. ${ }^{28}$ Helium, $99.99 \%$ purity, was the mobile phase. The column (HP5 MS) had a thickness of $0.25 \mu \mathrm{m}$, an internal diameter of $0.320 \mathrm{~mm}$, and length of $30 \mathrm{~m}$. Compounds were identified by comparing retention time and fragmentation pattern against the NIST mass spectra library.

\section{Statistical analysis}

The antioxidants, anti-inflammatory, and BSL assays were performed in duplicates and repeated in three independent experiments. The $50 \%$ inhibitory concentration $\left(I C_{50}\right)$ or lethal concentration $\left(\mathrm{LC}_{50}\right.$ ) values were expressed as mean \pm standard error of three independent data. The mean $\mathrm{IC}_{50}$ or $\mathrm{LC}_{50}$ comparison of the SPL with the standard drug was made with the Mann-Whitney $U$ test. $P$ value $<0.05$ was taken as significant.

\section{RESULTS}

SPL percentage yield extracted with $50 \%$ methanol was $29.3 \%$. The TFC and TPC of SPL extract were 190.29 $\pm 1.43 \mathrm{mg} \mathrm{RE} / \mathrm{g}$ and $609.5 \pm 0.42 \mathrm{mg} \mathrm{GAE} / \mathrm{g}$, respectively.

\section{Antioxidant activity and BSL of SPL}

The SPL antioxidant activity was concentration-dependent. Fifty percent $\mathrm{IC}_{50}$ in the DPPH and nitric oxide scavenging assays were $21.47 \pm 1.96$ and $49.49 \pm 1.24 \mu \mathrm{g} / \mathrm{mL}$, respectively (Table 1). Ascorbic acid gave an $\mathrm{IC}_{50}$ of $4.31 \pm 0.26$ and $48.74 \pm 1.41$ in DPPH and nitric oxide scavenging assays, respectively (Table 1). In the BSL test, $L C_{50}$ of $S P L$ was $455.58 \pm 82.35 \mu \mathrm{g} / \mathrm{mL}$ while cyclophosphamide was $16.3 \pm 0.15 \mathrm{mg} / \mathrm{mL}$ (Table 1).

\section{Anti-inflammatory activity}

The graded concentration effect of SPL on cell viability in LPS stimulated RAW 264.7 cells was assessed using MTT based assay. The concentration of SPL ranging from 50 to $400 \mu \mathrm{g} / \mathrm{mL}$ showed no effect on cell viability (Figure 1). Since SPL appeared non-toxic to RAW 264.7 cells at the tested concentration, its effect on nitrite production in LPS stimulated RAW 264.7 cells were assessed. SPL pre-treated LPS stimulated cells released a lower level of nitrite in the medium than the untreated control.

\section{Table 1. $\mathrm{IC}_{50}$ and $\mathrm{LC}_{50}$ of Salacia pallescens leaf (SPL)}

\begin{tabular}{|c|c|c|}
\hline $\mathrm{IC}_{50}$ or $\mathrm{LC}_{50}(\mu \mathrm{g} / \mathrm{mL})$ & S. pallescens & Standard drug \\
\hline${ }^{*} \mathrm{C}_{50} \mathrm{DPPH}$ inhibition & $21.47 \pm 1.96^{\#}$ & $4.31 \pm 0.26^{*}$ \\
\hline $\mathrm{IC}_{50}$ nitric oxide inhibition & $49.49 \pm 1.24$ & $48.74 \pm 1.41^{*}$ \\
\hline $\mathrm{LC}_{50}$ brine shrimp lethality test & $455.58 \pm 82.35^{\#}$ & $16.3 \pm 0.15^{\star *}$ \\
\hline
\end{tabular}

${ }^{*}$ Ascorbic acid, ${ }^{* *}$ Cyclophosphamide, " $S P L$ vs. control p<0.05, IC ${ }_{50}: 50 \%$ inhibitory concentration, $L C_{50}: 50 \%{ }_{\text {lethal }}$ concentration, DPPH: 1,1-diphenyl-2-picrylhydrazyl 
The SPL graded concentration $(50-400 \mu \mathrm{g} / \mathrm{mL}$ ) significantly inhibited nitrite production caused in LPS stimulated macrophages with inhibition ranging from 19.2 to $83.5 \%$ (Figure 2). Similarly, there was a 9-fold reduction in LPS induced IL-6 production in RAW 264.7 cells pre-treated with $400 \mu \mathrm{g} / \mathrm{mL}$ of SPL while pre-treatment with $50 \mu \mathrm{g} / \mathrm{mL}$ SPL resulted in a 1.4fold decrease in IL-6 production (Figure 3).

Phytochemical constituents of SPL

The retention time, abundance, and $m+1$ values of SPL are presented in Table 2. Sixteen compounds were identified

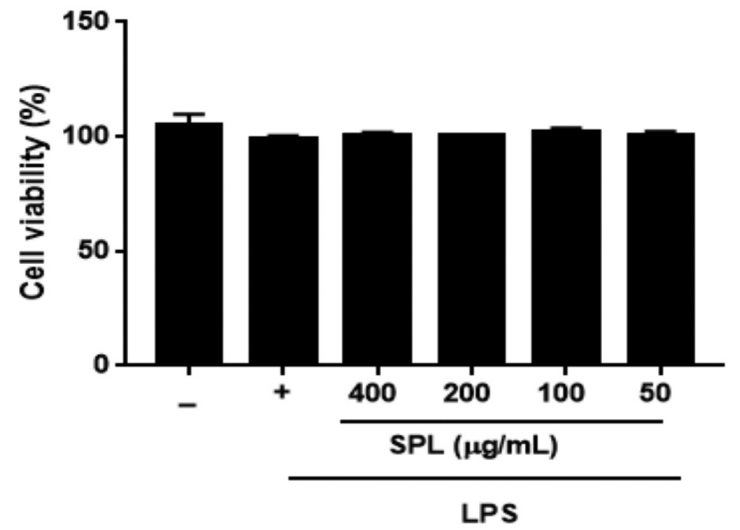

Figure 1. Effects of methanol extract of leaf of $S$. pallescens on cell viability in LPS stimulated RAW 264.7 cells. Data are expressed as means \pm SEM SPL: Salacia pallescens leaf, LPS: Liposacharride, SEM: Standard error of mean from the SPL extract. The most abundant compound is thymol (29.79\%), followed by 3-carene (15.97\%), p-cymene $(12.19 \%)$ caffeine (8.28\%), hexadecanoic acid (6.19\%), bicyclo[3.1.1]hept2-ene, 2,6-dimethyl-6-(4-methyl-3-pentenyl) (5.92\%), and caryophyllene $(5.17 \%)$. The mass spectra data depicted the fragmentation patterns and structures of the compounds in SPL are shown in Figure 4a-e.

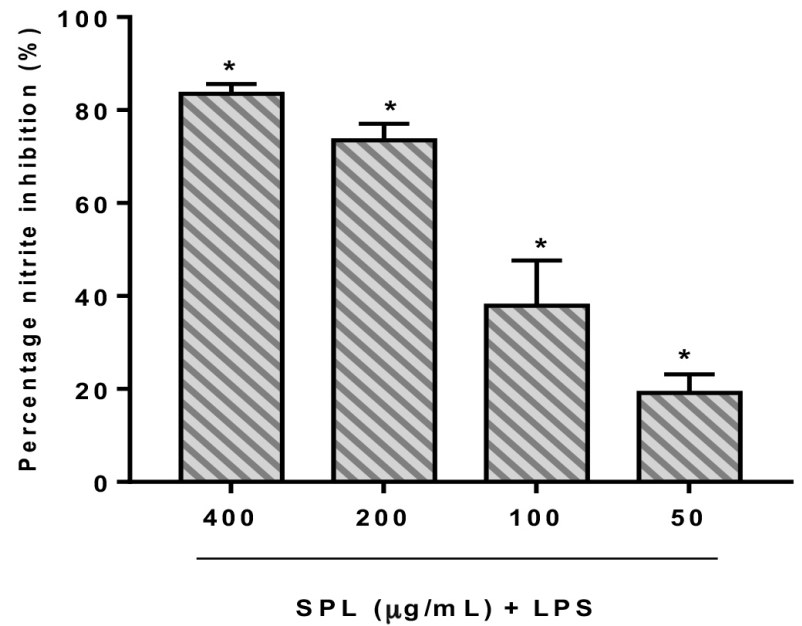

Figure 2. Inhibition of nitrite production in LPS stimulated RAW 264.7 cells by methanol extract of leaf of $S$. pallescens. Data are expressed as means \pm SEM

*Significant percentage reduction in nitrite production, SPL: Salacia pallescens leaf LPS: Liposacharride, SEM: Standard error of mean

\section{Table 2. Chemical compounds of ethyl acetate fraction of Salacia pallescens using GC-MS}

\begin{tabular}{|c|c|c|c|c|}
\hline GC peak & Compound names & GC-MS-RT (min) & Relative abundance \% & $M+1$ \\
\hline 1 & p-Cymene & 6.58 & 12.19 & 134 \\
\hline 2 & 1R)-2,6,6-Trimethylbicyclo[3.1.1] hept-2-ene & 7.10 & 1.82 & 136 \\
\hline 3 & 3-carene & 7.83 & 15.97 & 136 \\
\hline 4 & Methyl m-tolyl carbinol & 9.12 & 1.99 & 136 \\
\hline 5 & Benzene, 1-methoxy-4-methyl-2-(1-methylethyl)- & 9.91 & 1.44 & 164 \\
\hline 6 & Thymol & 10.88 & 29.79 & 150 \\
\hline 7 & 2-(Thiazolylazo)-p-cresol & 12.25 & 1.06 & 219 \\
\hline 8 & Caryophyllene & 12.70 & 5.17 & 204 \\
\hline 9 & Bicyclo[3.1.1]hept-2-ene, 2,6-dimethyl-6-(4-methyl-3-pentenyl)- & 12.83 & 5.92 & 204 \\
\hline 10 & Humulene & 13.17 & 0.97 & 204 \\
\hline 11 & $\begin{array}{l}\text { Naphthalene, decahydro-4a-methyl-1-methylene-7-(1- } \\
\text { methylethenyl)-, [4aR-(4a.alpha.,7.alpha.,8a.beta.)] }\end{array}$ & 13.62 & 4.08 & 204 \\
\hline 12 & 3,6-Nonadien-5-one, 2,2,8,8-tetram ethyl- & 13.72 & 1.43 & 190 \\
\hline 13 & Formamide, N-(4-benzofurazanyl)- & 17.93 & 2.24 & 101 \\
\hline 14 & Caffeine & 19.21 & 8.28 & 194 \\
\hline 15 & Hexadecanoic acid, methyl ester & 19.70 & 6.19 & 270 \\
\hline 16 & 9-Hexadecenoic acid & 22.59 & 1.47 & 254 \\
\hline
\end{tabular}

GC-MS: Gas chromatography-mass spectrometry, RT: Retention time 


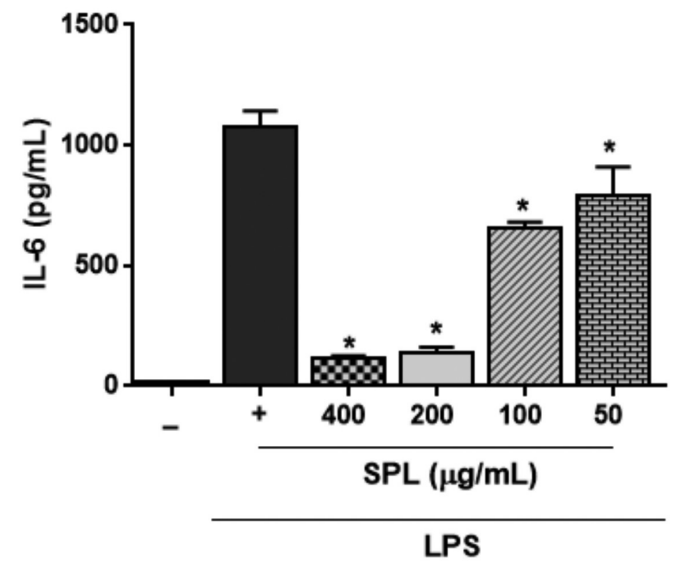

Figure 3. Effects of methanol extract of the leaf of S. pallescens on IL-6 production in LPS stimulated RAW264.7 cells. Data are expressed as means \pm SEM

*Significant percentage reduction in IL-6 production, SPL: Salacia pallescens leaf, LPS: Liposacharride, SEM: Standard error of mean, IL-6: Interleukin-6

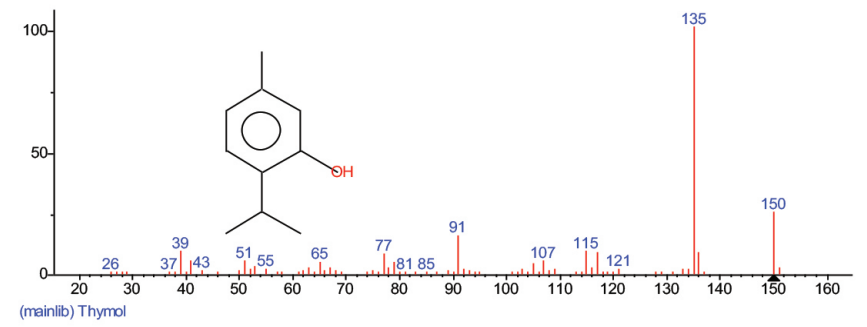

Figure 4a. Mass spectra and structure of thymol

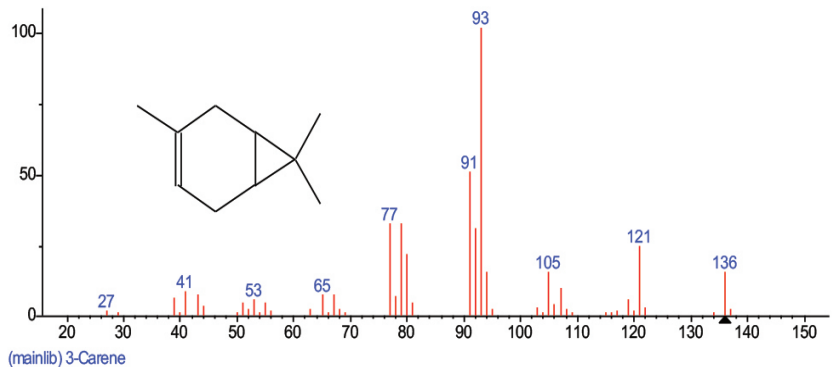

Figure 4b. Mass spectra and structure of 3-carene

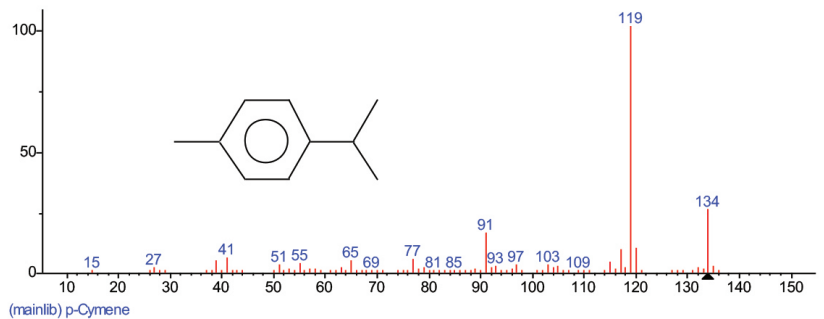

Figure 4c. Mass spectra and structure of p-cymene

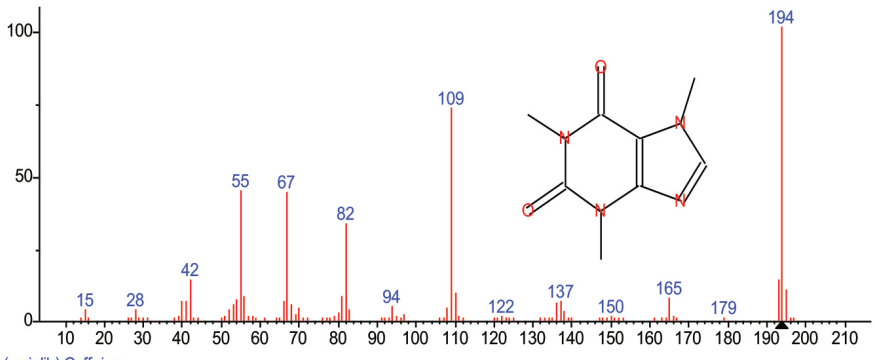
(mainlib) Caffeine

Figure 4d. Mass spectra and structure of caffeine

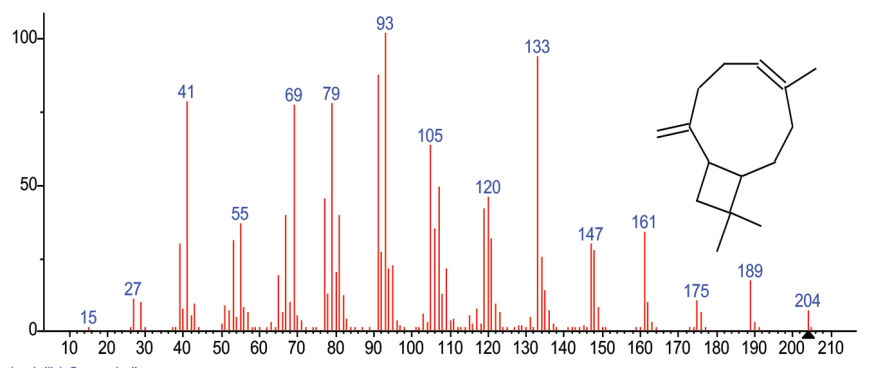

(mainlib) Caryophyllen

Figure 4e. Mass spectra and structure of caryophyllene

\section{DISCUSSION}

Findings in this study revealed that SPL possesses significant antioxidant activity. It scavenged free radicals generated by DPPH and nitric oxide in the DPPH- and sodium nitroprussidebased chemical assays. The high antioxidant property in plants is linked to its flavonoids and phenolic constituents, especially polyphenols, ${ }^{29,30}$ found in SPL. Previous studies have reported antioxidant activity of $S$. pallescens and other species such S. chinensis and S. oblonga. 12,31,32 Oxidative stress occurs due to the high production of free radicals like alkoxy, hydroxyl, superoxide, and nitric oxide and non-radical species such as peroxynitrite, hydrogen peroxide, and singlet oxygen. These free radical and non-radical species cause redox system alteration, induction of DNA damage, and procarcinogens activation, which are linked to pathological conditions' development and progression. ${ }^{33}$ Interestingly, the nitric oxide scavenging activity of SPL was comparable to ascorbic acid, a standard antioxidant drug, suggesting the benefit of the plant in controlling diseases associated with oxidative stress.

Liposaccharide stimulated RAW 264.7 cell is an antiinflammatory model for screening agents with anti-inflammatory properties. Overproduction of nitrite and accumulation of cytokines which amplifies the inflammation cascade are the main characteristics of this model..$^{34} \mathrm{SPL}$ significantly inhibited the overproduction of nitrite caused by liposaccharide and remarkably reduced the IL-6 level measured in this study. With the significant reduction of nitrite and IL-6 production, the leaf of $S$. pallescens demonstrated anti-inflammatory activity. To the best of our knowledge, this is the first anti-inflammatory activity report of S. pallescens. However, species of Salacia 
with in vivo anti-inflammatory activity include S. oblonga and S. lehmbachii. ${ }^{13,35}$

Furthermore, the cytotoxicity of SPL was evaluated to determine its safety profile. The SPL cytotoxicity was evaluated in the BSL test. SPL was not toxic on $A$. salina nauplii. $\mathrm{LC}_{50}$ value of less than $100 \mu \mathrm{g} / \mathrm{mL}$ was toxic, ${ }^{36}$ and SPL produced $\mathrm{LC}_{50}>400 \mu \mathrm{g} /$ $\mathrm{mL}$. Also, SPL was 28 times less toxic than cyclophosphamide, the standard drug. The BSL assay is used as a model for primary toxicity screening; ${ }^{37}$ additional complementing tests might be needed before drawing a safety conclusion. Additionally, it was observed that SPL does not affect the RAW 264.7 cells viability.

Besides that, 13 compounds were identified in SPL, where thymol had the highest relative abundance. Thymol, a monoterpene, possesses antifungal, antidepressant, and anti-inflammatory, and cicatrizing properties. ${ }^{38-40}$ The second most abundant compound was 3-Carene, a bicyclic monoterpene. 3-carene is one the major components of Bupleurum gibraltaricum essential oil with anti-inflammatory activity in carrageenan-induced paw edema in rats. ${ }^{41}$ Antibacterial activity of 3-carene against $B$. thermosphacta and $P$. fluorescens resulted in morphological, genomic damages, and eventual cell death to the bacterial has been reported. ${ }^{42}$ Also, 3-Carene exhibited a hypnotic effect in mice. ${ }^{43}$

Anti-inflammatory, anti-nociceptive, and antioxidant of p-Cymene, a monoterpene, the third most abundant in SPL, has been reported. ${ }^{4-46}$ Caffeine, a CNS and metabolic stimulant, is the fourth most abundant in SPL. Caffeine is a xanthine alkaloid present in 60 plant species. ${ }^{47}$ It has effects on smooth muscle, mood, memory, alertness, and physical and cognitive performance. ${ }^{47}$ Hexadecanoic acid, methyl ester, is also known as palmitic acid. Annona muricata L. seeds fixed oil contains palmitic acid and other fatty acids showing free radical scavenging activity. ${ }^{48}$ The antioxidant, anticancer, and anti-inflammatory activities of palmitic acid have been documented. ${ }^{49-51}$

Similarly, bicyclo [3.1.1] hept-2-ene, 2,6-dimethyl-6-(4-methyl3-pentenyl)- found in SPL has been reported to be present in Cinnamomum zeylanicum with antibacterial and anti-fungi activities. ${ }^{52}$ Likewise, antioxidant, anti-obesity, and antidiabetic activities of bicyclo [3.1.1] hept-2-ene, 2,6-dimethyl-6-(4-methyl3-pentenyl) in Ocimum basilicum has been documented. ${ }^{53}$ A bicyclic sesquiterpene, caryophyllene, also identified in SPL possesses anti-inflammatory activity by inhibiting proinflammatory cytokines, cyclooxygenase 1 and 2, and inducible nitric oxide synthase. ${ }^{54}$ Other pharmacological activities of caryophyllene include neuro-protective, anti-apoptosis, antioxidant, and analgesia. ${ }^{54-56}$ Naphthalene, decahydro-4amethyl-1-methylene-7-(1-methylethenyl)-, [4aR (4a.alpha.7. alpha, 8a.beta.)] also known as $\beta$-selinene, is another compound found in SPL. $\beta$-selinene a component of essential oils in Artemisia annua has antioxidant activity. ${ }^{57,58}$ Also, Callicarpa macrophylla $\beta$-selinene rich essential oils showed antioxidant anti-inflammatory, antipyretic, and analgesic properties. ${ }^{58}$

\section{CONCLUSION}

Methanol extract of SPL showed antioxidant and antiinflammatory activities by free radicals and cytokines inhibition. The extract appears to be non-toxic. The activities observed may be related to the polyphenolic compounds in the plant.

Conflict of interest: No conflict of interest was declared by the authors. The authors are solely responsible for the content and writing of this paper.

\section{REFERENCES}

1. Mittal M, Siddiqui MR, Tran K, Reddy SP, Malik AB. Reactive oxygen species in inflammation and tissue injury. Antioxid Redox Signal. 2014:20:1126-1167.

2. Ortega-Gómez A, Perretti M, Soehnlein O. Resolution of inflammation: an integrated view. EMBO Mol Med. 2013;5:661-674.

3. Mantovani A, Cassatella M.A, Costantini C, Jaillon S. Neutrophils in the activation and regulation of innate and adaptive immunity. Nat Rev Immunol. 2011;11:519-531.

4. Chelombitko MA. Role of reactive oxygen species in inflammation: a minireview. Moscow Univ Biol Sci Bull. 2018;73:199-202.

5. Fox S, Leitch AE, Duffin R, Haslett C, Rossi AG. Neutrophil apoptosis: relevance to the innate immune response and inflammatory disease. J Innate Immun. 2010;2:216-227.

6. Fadok VA, Bratton DL, Konowal A, Freed PW, Westcott JY, Henson PM. Macrophages that have ingested apoptotic cells in vitro inhibit proinflammatory cytokine production through autocrine/paracrine mechanisms involving TGF-beta, PGE2, and PAF. J Clin Invest. 1998;101:890-898

7. Michlewska S, Dransfield I, Megson IL, Rossi AG. Macrophage phagocytosis of apoptotic neutrophils is critically regulated by the opposing actions of pro-inflammatory and anti-inflammatory agents: key role for TNF-alpha. FASEB J. 2009;3:844-854.

8. Kunnumakkara AB, Sailo BL, Banik K, Harsha C, Prasad S, Gupta SC, Bharti AC, Aggarwal BB. Chronic diseases, inflammation, and spices: how are they linked? J Transl Med. 2018;16:14.

9. Atanasov AG, Waltenberger B, Pferschy-Wenzig EM, Linder T, Wawrosch C, Uhrin P, Temml V, Wang L, Schwaiger S, Heiss EH, Rollinger JM, Schuster D, Breuss JM, Bochkov V, Mihovilovic MD, Kopp B, Bauer R, Dirsch VM, Stuppner H. Discovery and resupply of pharmacologically active plant-derived natural products: a review. Biotechnol Adv. 2015;33:1582-1614.

10. Oguntibeju 00 . Medicinal plants with anti-inflammatory activities from selected countries and regions of Africa. J Inflamm. 2018;11:307-317.

11. Aworinde DO, Erinoso SM. Ethnobotanical investigation of indigenous plants used in the management of some infant illnesses in Ibadan, SouthWestern Nigeria Afr J Tradit Complement Altern Med. 2015;12:9-16.

12. Sofidiya MO, Odukoya OA, Familoni OB, Inya-Agha SI. Free radical scavenging activity of some nigerian medicinal plant extracts. Pak J Biol Sci. 2006;9:1438-1441.

13. Ismail TS, Gopalakrishnan S, Begum VH, Elango V. Anti-inflammatory activity of Salacia oblonga Wall. and Azima tetracantha Lam. J Ethnopharmacol. 1997;56:145-152.

14. Jansakul C, Jusapalo N, Mahattanadul S. Hypotensive effect of n-butanol extract from stem of Salacia chinensis in rats. Acta Hortic. 2005;678:107114. 
15. Minh TT, Hoang Anh, NT, Thang VD, Sung TV. Study on chemical constituents and cytotoxic activities of salacia chinensis growing in Vietnam. Z. Naturforsch 65b, 2010;1284-1288.

16. Asuti N. Hepatoprotective activity of ethanolic extract of root bark of Salacia chinensis. J Pharm Res. 2010;3:833-834.

17. He L, Qi Y, Rong X, Jiang J, Yang Q, Yamahara J, Murray M, Li Y. The ayurvedic medicine salacia oblonga attenuates diabetic renal fibrosis in rats: suppression of angiotensin ii/at1 signaling. Evid Based Complement Alternat Med. 2011;807451

18. Palani SS, Raja SS, Kumar S, Nirmal SN, Kumar B, Senthil BS. Nephroprotective and antioxidant activities of Salacia oblonga on acetaminophen-induced toxicity in rats. Nat Prod Res. 2011;25:18761880.

19. Bhat BM, Raghuveer CV, D'Souza V, Manjrekar PA. Antidiabetic and hypolipidemic effect of Salacia oblonga in streptozotocin induced diabetic rats. J Clin Diagn Res. 2012;6:1685-1687.

20. Basu S, Pant M, Rachana R. In vitro antioxidant activity of methanolicaqueous extract powder (root and stem) of Salacia oblonga. Int J Pharm Sci Res. 2013;5:904-909.

21. Park YS, Jung ST, Kang SG, Heo BK, Arancibia AP, Toledo F, Drzewiecki $\mathrm{J}$, Gorinstein S. Antioxidants and proteins in ethylene-treated kiwi fruits. Food Chem. 2008;107:640-648.

22. Kim D, Jeong SW, Lee CY. Antioxidant capacity of phenolic phytochemicals from various cultivars of plums. Food Chem. 2003;81:321-326.

23. Abiodun 00 , Tijani R, Ogbole O, Ajaiyeoba E. Antioxidant, alpha-amylase and alphaglucosidase inhibitory activities of leaf and flower extracts and fractions of Phaulopsis falcisepala C. B. Clarke. Acta Pharm Sci. 2018;56:23-33.

24. Panda BN, Raj AB, Shrivastava NR, Prathani AR. The evaluation of nitric oxide scavenging activity of acalypha indica linn root. Asian $\mathrm{J}$ Chem. 2009;2:148-150.

25. Mosmann T. Rapid colorimetric assay for cellular growth and survival: application to proliferation and cytotoxicity assays. J Immunol Methods. 1983;65:55-63.

26. Green LC, Wagner DA, Glogowski J, Skipper PL, Wishnok, JS, Tannenbaum SR. Analysis of nitrate, nitrite, and [15N] nitrate in biological fluids. Anal Biochem. 1982;126:131-138.

27. Ajaiyeoba EO, Abiodun OO, Falade MO, Ogbole NO, Ashidi JS, Happi CT, Akinboye DO. In vitro cytotoxicity studies of 20 plants used in Nigerian antimalarial ethnomedicine. Phytomedicine. 2006;13:295-298.

28. Wangchuk P, Kellera PA, Pynea SG, Taweechotipatr M, Kamchonwongpaisan S. GC/GC-MS analysis, isolation and identification of bioactive essential oil components from the bhutanese medicinal plant, pleurospermum amabile. Nat Prod Commun. 2013;8:1305-1308.

29. Abuashwashi MA, Palomino OM, Gomez-Serranillos MP. Geographic origin influences the phenolic composition and antioxidant potential of wild Crataegus monogyna from Spain. Pharm Biol. 2016;54:2708-2713.

30. Mfotie NE, Munvera AM, Mkounga, P Nkengfack AE, McGaw LJ. Phytochemical analysis with free radical scavenging, nitric oxide inhibition and antiproliferative activity of Sarcocephalus pobeguinii extracts. BMC Complement Altern Med. 2017;17:199.

31. Musini A, Rao JP, Giri A. Phytochemicals of Salacia oblonga responsible for free radical scavenging and antiproliferative activity against breast cancer cell lines (MDA-MB-231). Physiol Mol Biol Plants. 2015;21:583590.
32. Thanh VN, Christopher JS, Michael CB Quan Van V. Phytochemical and antioxidant properties from different parts of Salacia Chinensis $L$. J Biol Act Prod Nat. 2017;7:5:401-410.

33. Pacher P, Beckman JS, Liaudet L. Nitric oxide and peroxynitrite in health and disease. Physiol Rev. 2007;87:315-424.

34. Schulte W, Bernhagen J, Bucala R. Cytokines in sepsis: potent immunoregulators and potential therapeutic targets-an updated view. Mediators Inflamm. 2013;165974.

35. Takem LP, Lawal BAS, Udia PM. Analgesic and acute anti-inflammatory activities of aqueous root extract of salacia lehmbachii. J Pharm Res Int. 2014:4:2172-2181.

36. Rieser MJ, Fang XP, Gu ZM, Zhao GX, McLaughlin JL. Annonanceous acetogenins. Phytochem Anal. 1993;4:27-48.

37. Ogbole OO, Aliu LO, Abiodun OO, Ajaiyeoba EO. Alpha-amylase inhibition and brine shrimp lethality activities of nine medicinal plant extracts from South-West Nigerian Ethnomedicine. J Herbs Spices Med Plants. 2016;22:319-326.

38. Segvić KM, Kosalec I, Mastelić J, Piecková E, Pepeljnak S. Antifungal activity of thyme (Thymus vulgaris L.) essential oil and thymol against moulds from damp dwellings. Lett Appl Microbiol. 2007;44:36-42.

39. Riella KR, Marinho RR, Santos JS, Pereira-Filho RN, Cardoso JC, Albuquerque-Junior RL, Thomazzi SMJ. Anti-inflammatory and cicatrizing activities of thymol, a monoterpene of the essential oil from Lippia gracilis, in rodents. J Ethnopharmacol. 2012;143:656-663.

40. Nagoor Meeran MF, Javed H, Al Taee H, Azimullah S, Ojha SK. Pharmacological properties and molecular mechanisms of thymol: prospects for its therapeutic potential and pharmaceutical development. Front Pharmacol. 2017;26:380.

41. Ocete MA, Risco S, Zarzuelo A, Jimenez JJ. Pharmacological activity of the essential oil of Bupleurum gibraltaricum: anti-inflammatory activity and effects on isolated rat uteri. J Ethnopharmacol. 1989;25:305-313.

42. Huizhen S, Haiming C, Xiaolong W, Yueying $H$, Yonghuan $Y$, Qiuping Z, Weijun $C$, Wenxue C. Antimicrobial activity and proposed action mechanism of 3-carene against brochothrix thermosphacta and pseudomonas fluorescens. Molecules. 2019;24:3246.

43. Yang H, Woo J, Pae AN, Um MY, Cho NC, Park KD, Yoon M, Kim J, Lee $\mathrm{CJ}$, Cho S. $\alpha$-pinene, a major constituent of pine tree oils, enhances non-rapid eye movement sleep in mice through GABAA-benzodiazepine receptors. Mol Pharmacol. 2016;90:530-539.

44. Bonjardim LR, Cunha ES, Guimarães AG, Santana MF, Oliveira MG, Serafini MR, Araújo AA, Antoniolli AR, Cavalcanti SC, Santos MR, QuintansJúnior LJZ. Evaluation of the antiinflammatory and antinociceptive properties of p-cymene in mice. Z Naturforsch C J Biosci. 2012;67:15-21.

45. Quintans-Júnior L, Moreira JC, Pasquali MA, Rabie SM, Pires AS, Schröder R, Rabelo TK, Santos JP, Lima PS, Cavalcanti SC, Araújo AA, Quintans JS, Gelain DP. Antinociceptive activity and redox profile of the monoterpenes $(+)$-camphene, $p$-cymene, and geranyl acetate in experimental models. ISRN Toxicology. 2013;459530.

46. de Santana MF, Guimarães AG, Chaves DO, Silva JC, Bonjardim LR, de Lucca Júnior W, Ferro JN, Barreto EO, dos Santos FE, Soares MB, Villarreal CF, Quintans JS, Quintans-Júnior LJ. The anti-hyperalgesic and anti-inflammatory profiles of $\mathrm{p}$-cymene: evidence for the involvement of opioid system and cytokines. Pharm Biol. 2015;53:1583-1590.

47. Uddin S, Sufian HF, Kabir T, Islam T, Rahman M, Rafe R. Neuropsychological effects of caffeine: is caffeine addictive? Int J Psychol Couns. 2017;7:295. 
48. Elagba ZA, Naik RR, Shakya AK, Bardaweel SK. Fatty acids analysis, antioxidant and biological activity of fixed oil of Annona muricata L. Seeds. J Chem. 2016;6948098.

49. Harada H, Yamashita U, Kurihara H, Fukushi E, Kawabata J, Kamei Y. Antitumor activity of palmitic acid found as a selective cytotoxic substance in a marine red alga. Anticancer Res. 2002;22:2587-2590.

50. Kumar P, Kumaravel S, Lalitha C. Screening of antioxidant activity, total phenolics and GC-MS study of Vitex negundo. Afr J Biochem Res. 2010;4:191-195.

51. Aparna V, Dileep KV, Mandal PK, Karthe P, Sadasivan C, Haridas M. Antiinflammatory property of $\mathrm{n}$-hexadecanoic acid: structural evidence and kinetic assessment. Chem Biol Drug Des. 2012;80:434-439.

52. Hameed IH, Altameme HJ, Mohammed GJ. Evaluation of antifungal and antibacterial activity and analysis of bioactive phytochemical compounds of cinnamomum zeylanicum (cinnamon bark) using gas chromatographymass spectrometry. Orient J Chem. 2016;32:1769-1788.

53. Noor Zl, Ahmed D, Rehman HM, Qamar MT, Froeyen M, Ahmad S, Mirza MU. In vitro antidiabetic, anti-obesity and antioxidant analysis of ocimum basilicum aerial biomass and in silico molecular docking simulations with alpha-amylase and lipase enzymes. Biology. 2019;8:92.
54. Francomano F, Caruso A, Barbarossa A, Fazio A, La Torre C, Ceramella J, Mallamaci R, Saturnino C, lacopetta D, Sinicropi MS. $\beta$-Caryophyllene: a sesquiterpene with countless biological properties. Appl Sci. 2019;9:5420.

55. Viveros-Paredes J.M, González-Castañeda RE, Gertsch J, ChaparroHuerta, V, López-Roa RI, Vázquez-Valls E, Beas-Zarate C, CaminsEspuny A, Flores-Soto ME. Neuroprotective effects of $\beta$-caryophyllene against dopaminergic neuron injury in a murine model of parkinson's disease induced by MPTP. Pharmaceuticals. 2017;10:60.

56. Lou J, Teng Z, Zhang L, Yang J, Ma L, Wang F, Tian X, An R, Yang M, Zhang $Q, \quad X u$ LD. Z $\beta$-caryophyllene/hydroxypropyl- $\beta$-cyclodextrin inclusion complex improves cognitive deficits in rats with vascular dementia through the cannabinoid receptor type 2-mediated pathway. Front Pharmacol. 2017;8:2.

57. Zhigzhitzhapova SV, Dylenova EP, Gulyaev SM, Randalova TE, Taraskin VV, Tykheev ZA, Radnaeva LD. Composition and antioxidant activity of the essential oil of Artemisia annua L. Nat Prod Res. 2019;9:1-4.

58. Chandra M, Prakash O, Kumar R, Bachheti RK, Bhushan B, Kumar M, Pant AK. $\beta$-selinene-rich essential oils from the parts of callicarpa macrophylla and their antioxidant and pharmacological activities. Medicines (Basel). 2017;4:52. 